\title{
DOES THE ADDITION OF DEXAMETHASON TO LOCAL ANESTHETIC PROLONG THE ANALGESIA OF INTERSCALEN PLEXUS BRACHIALIS BLOCK IN PATIENTS WITH SHOULDER SURGERY?
}

\author{
Nancheva Jasminka, Andonovski Alan, Georgieva Daniela, Bozinovski Zoran, \\ Dzoleva Roza,Gavrilovski Antonio, Georgiev Antonio \\ University Clinic for Orthopaedic Surgery, Medical Faculty Skopje, Republic of Macedonia
}

Primljen/Received 30. 01. 2016. god.

Abstract: Introduction: Peripherial nerve blocks is a suitable alternative to general anesthesia especially for one-day case surgery. Interscalene approach of plexus brachialis block as much as supraclavicular and infraclavicular provide reliable, safe, effective, low cost and most complete anesthesia with satisfactory postoperative analgesia for upper limb surgery. Postoperative analgesia of plexus brachialis blocks can be prolonged by using different drugs as adjuvants with local anesthetics. Dexamethasone has been shown to prolong the duration of postoperative analgesia when given as an adjunct for peripheral nerve blocks. The investigation was randomized, prospective, double blinded and controlled study.

Objective: The study was designed to compare the effects of dexamethasone administered as an adjunct to bupivacaine in interscalene brachial plexus block on the onset, duration and postoperative analgesia in patients under the shoulder surgery.

Methods: A prospective, double-blind study was undertaken in patients scheduled for shoulder surgeries under the interscalene brachial plexus block. We enrolled 60 patients, ASA I-II both sexes, aged 19-65 years, weighing $54-89 \mathrm{~kg}$, divided to two groups G1 and G2. The brachial plexus block was performed by interscalene approach and mixture of $2 \%$ lidocaine $(12 \mathrm{ml})$ and $0.5 \%$ bupivacaine $(22 \mathrm{ml})$ either alone or combined with dexamethasone $(4 \mathrm{mg})$. The block was performed by using double technique neurostimulator/ultrasound technique.

Results: In our investigation we found a significant increase in onset and duration of motor and sensory block in Group G2 (with dexamethasone) as compared to Group G1 patients $(\mathrm{p}<0.01)$.

Conclusion: Addition of dexamethasone to local anesthetic drugs in interscalene plexus brachialis block,
Prihvaćen/Accepted 01. 03. 2016. god.

significantly prolongs the duration of analgesia and motor block in patients undergoing shoulder arthroscopy. Moreover, it is a remarkably safe and cost effective method of providing postoperative analgesia.

Key words: regional anesthesia, interscalene plexus block, adjuvants, dexamethasone.

\section{INTRODUCTION}

Peripherial nerve blocks is a suitable alternative to general anesthesia especially for one-day case surgery. Interscalene approach of plexus brachialis block as much as supraclavicular and infraclavicular provide reliable, safe, effective, low cost and most complete anesthesia with satisfactory postoperative analgesia for upper limb surgery. Pneumothorax, hemothorax, Horner's syndrome and phrenic nerve block are the potential complications (1). Generally, a major limitation of peripheral nerve blocks can be a limited duration of analgesia (2). In order to circumvent that limitation, peripheral nerve catheters that offer continuously delivery of local anesthetics have been proposed as an efficient method of postoperative analgesia (3). Nevertheless, peripheral nerve catheters are costly and can be cumbersome to manage in the outpatient surgical setting $(3,4)$. Also, postoperative analgesia of peripheral nerve blocks can be prolonged by using different drugs as adjuvant with local anesthetics, such as morphine, ephedrine, pethidine, clonidine, dexmedetomidine, butorphanol, buprenorphine, midazolam $(5,6,7)$. However, these may lead to certain side-effects such as sedation, psychomimetic effects, respiratory depression, pruritis, etc $(6,7)$. The ideal adjuvant that acts to prolong anesthesia and improve clinical outcomes while maintaining a favorable side effect profile, remains undiscovered. 
Recently, several studies have examined the use of perineural dexamethasone in order to prolong analgestic duration of peripheral nerve blocks with variable results. However, the aggregated effect of perineural dexamethasone on analgesia outcomes has yet to be quantified. In addition, the safety of perineural dexamethasone also needs to be further examined (8). Dexamethasone is a systemic glucocorticoid commonly used to reduce postoperative nausea/vomiting, pain and to improve quality of recovery after surgery. Preliminary studies suggest that its addition can impressively prolong the duration of analgesia of peripheral nerve block with minimal adverse effects (7). The exact mechanism of dexamethasone's action is still unknown. It has been suggested that dexamethasone may prolong block duration by increasing the activity of inhibitory potassium channels on nociceptive $\mathrm{C}$-fibers or by causing vasoconstriction via glucocorticoid receptor mediated nuclear transcription modulation $(8,9)$. Dexamethasone's suppression of inflammatory mediators, including prostaglandins (PGE2), may also play a role. Indirect evidence has supported the assumption that dexamethasone acts locally, however recent studies have suggested a systemic effect may be responsible for its clinical effect and intravenous administration may give similar results (9).

The investigation was randomized, prospective, double blinded and controlled study. The purpose of this study was to compare the effects of dexamethasone administered as an adjunct to bupivacaine in interscalene plexus brachialis block, on the onset and duration of analgesia and motor blockade at the patients with shoulder surgery.

\section{MATERIAL AND METHODS}

After ethical committe approval and informed consent, we enrolled 60 patients, ASA I-II of either sexes, aged 19-65 years, weighing $54-89 \mathrm{~kg}$, undergoing shoulder surgery. The brachial plexus block was performed by interscalene approach and mixture of lidocaine and bupivacaine either alone or combined with dexamethasone. The block was performed by using double technique neurostimulator/ultrasound technique.

Exclusion criteria in this investigation were:

- Refusal to regional anesthesia

- ASA Grade 3 and 4

- Any bleeding disorder in patient with anticoagulants

- Severe respiratory disease

- Neuro deficit involving brachial plexus

- Local infection at the injection site

- History of allergy to local anaesthetic
- Patients with a history of peptic ulcer disease, diabetes mellitus, hepatic or renal failure (contraindication to steroids, or systemic use of corticosteroids within 6 months before surgery)

- Pregnant women

Investigations: X-ray chest, basic laboratory investigations, EKG (electrocardiogram). All the patients were premedicated with tablets from the group of benzodiazepams, night before surgery and one hour prior to surgery.

Baseline parameters were recorded by attaching all the basic monitoring devices like oxygen saturation (SpO2), electrocardiogram (EKG), noninvasive blood pressure (NIBP). Patients were randomly divided in two groups, G1 and G2 with 30 of them in each group. Group G1: Patients received mixture of $2 \%$ lidocain $(12 \mathrm{ml})$ and $0.5 \%$ bupivacaine $(22 \mathrm{ml})$ plus $1 \mathrm{ml} 0.9 \%$ normal saline, making a total volume of $35 \mathrm{ml}$, through the interscalene approach of plexus brachialis.

Group G2: Patients received mixture of $2 \%$ lidocain $(12 \mathrm{ml})$ and $0.5 \%$ bupivacaine $(22 \mathrm{ml})$ plus $4 \mathrm{mg}$ $(1 \mathrm{ml})$ dexamethasone, making a total volume of $35 \mathrm{ml}$, through the interscalene approach of plexus brachialis.

\section{The following parameters were studied:}

- Onset of sensory block was tested by using pin prick method along the distribution of the shoulder and humerus i.e. the time from injection to onset of analgesia in five time intervals $(\mathrm{min}) 0,10,15,20,25$ and 30 min. Sensory block was graded according to the following scale: $0=$ no block (normal sensation), $1=$ partial block (decreased sensation), and $2=$ complete block (no sensation). The first time interval "0" we do not analyzed, because in all 60 patients we had not noticeable changing in sensory and motor block, so the real first examinated time interval was $10 \mathrm{~min}$.

\section{- Duration of analgesia:}

During the procedure, anesthesia was considered satisfactory if the patient did not complain of any pain or discomfort and if no sedation was necessary.

Post operative follow up was carried out in the recovery and post operative ward. The duration of analgesia was noted according to $0-10$ visual analogue score (VAS) for pain at every half an hour for first 10 hours and then hourly till 24 hours.

When the patients began to experience the worst pain VAS $\geq 5$, it was considered that analgesic action of the drugs was terminated and rescue analgesic given.

- Onset of motor block is the time from injection to the inability of the patient to move his/her fingers or raise their hand. Motor block was measured at 10, 15, 20, 25 and 30 min by assessing the following motor functions: flexion at the elbow (musculocutaneous nerve), extension of the elbow and the wrist (radial nerve), op- 
position of the thumb and index finger (median nerve), and opposition of the thumb and small finger (ulnar nerve). Motor block was graded according to the following scale: $0=$ no block (full muscle activity), $1=$ partial block (decreased muscle activity), and 2 = complete block (no muscle activity).

- Duration of motor block postoperatively was assessed every hour by asking the patients to move their fingers, hand, flexion and extension at the elbow. This time was recorded and taken as cessation of motor block effect.

\section{Possible side effects of brachial plexus block}

Incidence of drowsiness, pruritus, nausea/vomiting, Horner's syndrome, phrenic nerve palsy, pneumothorax, respiratory depression and sign of symptoms for local anaesthetic toxicity were looked for and noted, if any.

During the anesthesia plexus brachialis block is excellent if there is no discomfort or pain, good (mild pain or discomfort, no need for additional analgesics), fair (pain that required additional analgesics) or poor (moderate or severe pain that needed fentanyl or general anesthesia). In the circumstance of inadequate action of the block, the block would be supplemented with general anaesthesia. If in case surgery was unduly prolonged and the effect of the block wore off, rescue analgesia with IV hypnotic and analgetic would be given.

\section{Statistical analysis}

The data obtained in this study was arranged in tables and presented in frequencies and percentage. The analysis used Student's unpaired t-test, SPSS ver. 20 was used.

\section{RESULTS}

The patients data of analgesia were presented as level 1 = partial block (decreased sensation) and level 2 = complete block (no sensation). They were displayed through five time intervals as frequencies and percentage in two examined groups (Table 1).

Table 1. Comparison of onset of analgesia

\begin{tabular}{|c|c|c|c|c|}
\hline Level of analgesia & $\begin{array}{c}\text { Time interval } \\
(\mathrm{min})\end{array}$ & $\mathrm{G} 1$ & $\mathrm{G} 2$ & $\begin{array}{c}\text { Level of } \\
\text { significance }\end{array}$ \\
\hline \multirow{4}{*}{1} & 10 & $3(10 \%)$ & $25(83 \%)$ & $\mathrm{p} \leq 0,01$ \\
\cline { 2 - 5 } & 15 & $24(80 \%)$ & $5(17 \%)$ & $\mathrm{p} \leq 0,01$ \\
\cline { 2 - 5 } & 20 & $9(30 \%)$ & $1(3 \%)$ & $/$ \\
\cline { 2 - 5 } & 25 & $2(7 \%)$ & $1(3 \%)$ & $/$ \\
\hline \multirow{4}{*}{2} & 30 & $2(7 \%)$ & $2(7 \%)$ & $/$ \\
\cline { 2 - 5 } & 10 & $/$ & $/$ & $\mathrm{p} \leq 0,01$ \\
\cline { 2 - 5 } & 15 & $2(13 \%)$ & $23(77 \%)$ & $\mathrm{p} \leq 0,01$ \\
\cline { 2 - 5 } & 20 & $28(93 \%)$ & $28(93 \%)$ & n.s. \\
\cline { 2 - 5 } & 25 & $28(93 \%)$ & $28 \%(93 \%)$ & n.s. \\
\hline
\end{tabular}

Table 2. Comparison of onset of motor block

\begin{tabular}{|c|c|c|c|c|}
\hline $\begin{array}{c}\text { Level of motor } \\
\text { block }\end{array}$ & $\begin{array}{c}\text { Time interval } \\
(\mathrm{min})\end{array}$ & G1 & G2 & $\begin{array}{c}\text { Level of } \\
\text { significance }\end{array}$ \\
\hline \multirow{4}{*}{1} & 10 & $4(13 \%)$ & $26(87 \%)$ & $\mathrm{p} \leq 0.01$ \\
\cline { 2 - 5 } & 15 & $23(77 \%)$ & $7(23 \%)$ & $\mathrm{p} \leq 0.01$ \\
\cline { 2 - 5 } & 20 & $3(10 \%)$ & $1(3 \%)$ & $/$ \\
\cline { 2 - 5 } & 25 & $2(7 \%)$ & $1(3 \%)$ & $/$ \\
\hline \multirow{6}{*}{2} & 30 & $2(7 \%)$ & $2(7 \%)$ & $/$ \\
\cline { 2 - 5 } & 10 & 1 & $1(3 \%)$ & $\mathrm{p} \leq 0.01$ \\
\cline { 2 - 5 } & 15 & $26(87 \%)$ & $28(93 \%)$ & $\mathrm{p} \leq 0.05$ \\
\cline { 2 - 5 } & 20 & $28(93 \%)$ & $28(93 \%)$ & $\mathrm{n}$. .s. \\
\cline { 2 - 5 } & 25 & $28(93 \%)$ & $28(93 \%)$ & n.s. \\
\hline
\end{tabular}


Table 3. Comparison of duration of analgesia and motor block

\begin{tabular}{|c|c|c|c|}
\hline Variable & Groups & $\begin{array}{c}\text { Mean } \pm \text { SD } \\
(\mathrm{hr})\end{array}$ & $\begin{array}{c}\text { Level of } \\
\text { significance }\end{array}$ \\
\hline \multirow{2}{*}{$\begin{array}{c}\text { Duration } \\
\text { of analgesia }\end{array}$} & $\mathrm{G} 1$ & $9.3 \pm 1.25$ & $\mathrm{p} \leq 0.01$ \\
\cline { 2 - 3 } $\begin{array}{c}\text { Duration } \\
\text { of motor block }\end{array}$ & $\mathrm{G} 2$ & $16.1 \pm 2.55$ & \multirow{2}{*}{$\mathrm{p} \leq 0.01$} \\
\cline { 2 - 3 } & $\mathrm{G} 1$ & $6.6 \pm 1.50$ & $10.5 \pm 2.30$ \\
\hline
\end{tabular}

The analysis showed significant difference $(\mathrm{p} \leq$ $0,01)$ in level 1 between data in two time intervals $(10$ min., 15 min.). In level 2 data from group of patients with dexamethasone (G2) have significant increase of complete analgesia (77\% and 93\%). In last two intervals (25 min., $30 \mathrm{~min}$.) the data were not significant, because the interscalene plexus block was established.

The motor block was established in the first time interval with significant high percent of patients with dexamethasone (table 2). In Group 1, most of patients (77\%) had incomplete motor block in the first 15 minutes. The appearance of complete motor block began between 20-25 min. The difference is significant in mentioned time interval.

Duration of motor block and duration of analgesia were prolonged in dexamethasone group compared to control group. Statistical difference between examined groups in both variables was significant $(p \leq 0,01)$. Interscalene plexus block anesthesia was unsuccessful in four patients (two of each group). Additional side effects as potential complications like Horner's syndrome was found in 6 patients from group G1 and 4 from group G2.

\section{DISCUSSION}

Interscalene plexus brachialis block is a simple, safe, low cost, effective technique of regional anesthesia having advantages over general, especially for one day case shoulder surgery. Interscalene plexus brachialis block over general anesthesia provide postoperative longer period of analgesia without problems associated with general anesthesia $(4,10)$. Prolonging surgical anesthesia and analgesia is of significant interest in regional anesthesia, especially in plexus brachialis block. There are two solutions in order to increase the duration of analgesia in these blocks, a) using peripheral nerve catheters which offer continuously delivery of local anesthetics and b) adding the adjuvants in local anesthetic $(3,4)$. Nevertheless, peripheral nerve catheters are costly and can be cumbersome to manage in the outpatient surgical setting (4).

The adjuvants added in plexus brachialis block such as morphine, ephedrine, pethidine, clonidine, dex- medetomidine, butorphanol, buprenorphine, midazolam provide prolongation of sensory and motor block. Recently, the addition of a glucocorticoid specifically, dexamethasone, has been studied with high quality outcome. Many literature reviews concluded that analgetic effect of dexamethasone works by:

- reducing the transmission in unmyelinated C-fibers through inhibiting the activity of potassium channels, that will decrease the amount of pain sensed by patient

- causes a degree of local tissue vasoconstriction and provides a slower uptake of local anesthetic

- dexamethasone exhibits a potent anti-inflammatory effect and inhibits the release of inflammatory mediators like interleukins and cytokines, it promotes the release of antiinflammatory mediators leading to decreased postoperative pain $(11,12)$.

In our study we evaluated 60 patients with shoulder artroscopy, that underwent the interscalene plexus brachialis block. Dexsamethasone $4 \mathrm{mg}$ was used as a adjuvant added in local anesthetics. The most recent study included the higher dose of dexamethasone such as $8 \mathrm{mg}, 10 \mathrm{mg}$, so the main point in our study was to investigate if the dose of $4 \mathrm{mg}$ dexamethasone affects the onset of sensation and motor block as well, if this corticosteroid prolongs duration of analgesia and motor blockade, compare to group of patient without dexamethason in interscalene block $(13,14)$. The results in our study shows that the onset of sensation (level 1) in $\mathrm{G} 2$ (with dexamethasone) in $87 \%$ of patients were performed in the first time interval ( $10 \mathrm{~min})$, and the interscalene block was completely established between 15-20 min, compare to G1 group where the block in most of patients was resolved between $20-25 \mathrm{~min}$. ( $\mathrm{p} \leq$ 0.01 ). The motor block was established in the first time interval with significant higher percentage of patients in group G2 ( with dexamethasone). In Group 1, the most patients (77\%) had incomplete motor block in the first 15 minutes. The appearance of complete motor block began between 20-25 min. The difference between two groups is significant in mentioned time interval $(\mathrm{p} \leq 0.01)$.

In one study by Shrestha BR, onset of action was 10-30 minutes in local anesthetic group (mean $18.15 \pm$ 
4.25 ) and 10-20 minutes (mean $14.5 \pm 2.10$ ) in the local anesthetic plus steroid, group. They found statistically significant difference between two groups (15). However another study by Ali Movafegh, found that the onset time of sensory and motor blockade was similar in both groups (with and without dexamethasone) (16).

In our study the duration of analgesia in dexamethasone group G2 was $16,1 \pm 2,55$ h longer than in G1 $9.39 \pm 1,25(\mathrm{P} \leq 0.01)$. The mean duration of motor block in G2 was 10,5 $\pm 2,30 \mathrm{~h}$ and in G1 6,6 $\pm 1,50 \mathrm{~h}(\mathrm{P}$ $\leq 0.01)$. Cummings reported that dexamethasone prolonged analgesia from interscalene blocks using ropivacaine and bupivacaine, with the effect being stronger with ropivacaine (17). Pathak reported that the duration of analgesia and motor block were significantly prolonged in patients ( with dexamethasone) with supraclavicular plexus block undergoing upper limb surgery, compared to the control group (without dexamethasone) (13). Parrington showed that dexamethasone added to mepivacaine prolongs the duration of analgesia (332 min vs. $228 \mathrm{~min}$ in control group) after supraclavicular brachial plexus block. The onset time of sensory and motor blocks were similar in both groups (14).

In a randomized, control trials by Desmet et al. and Shahedha et al. a study was performed on intravenous dexamethasone and its equality to perineural dexamethasone in prolonging the analgesic duration of a single-shot interscalene block with ropivacaine $(5,18)$.

The efficiency of dexamethasone in prolonging the duration of analgesia and motor block in patients operated under the plexus brachialis blocks, were noticed also in other peripherial blocks like peribulbar block in posterior segment eye surgery, axillary block, sciatic block etc $(19,20)$.

\section{CONCLUSION}

Addition of dexamethasone to local anesthetic drugs in interscalene plexus brachialis block, significantly prolongs the duration of analgesia and motor block in patients undergoing shoulder artroscopy and is a remarkably safe and cost effective method of providing post operative analgesia. A patient with reduced pain and a reduced need for additional analgesics post operatively is always a satisfied customer.

\section{Conflict of interest}

The authors declare are no conflict of interest.

Abbreviations
PGE2 - Prostaglandins
ASA - American Association of Anesthesiolo-
gists
EKG - Electrocardiogram
SpO - Oxygen Saturation
NIBP - Non invasive blood pressure
VAS - Visual Analogue Scale
SPSS - Statistical Package for the Social Sciences

\title{
Sažetak
}

\section{DA LI DODATAK DEKSAMETAZONA LOKALNOM ANESTETIKU PRODUŽAVA TRAJANJE ANALGEZIJE KOD INTERSKALENSKOG BLOKA PLEKSUSA BRAHIJALISA KOD PACIJENATA SA OPERACIJOM RAMENA?}

\author{
Nancheva Jasminka, Andonovski Alan, Georgieva Daniela, Bozinovski Zoran, \\ Dzoleva Roza,Gavrilovski Antonio, Georgiev Antonio \\ University Clinic for Orthopaedic Surgery, Medical Faculty Skopje, Republic of Macedonia
}

Uvod: Blokovi perifernih nerava su odgovarajuća zamena za generalnu anesteziju, posebno u jednodnevnim, kratkim hirurškim intervencijama. Interskaleni blok pleksusa brahijalisa, podjednako kao i supraklavikularni i infraklavikularni obezbeđuje pouzdanu, sigurnu, efektivnu, ekonomičnu i najkompletniju anesteziju sa zadovoljavajućom postoperativnom analgezijom za operacije gornjeg ekstremiteta. Postoperativna analgezija bloka pleksusa brahijalisa može biti produžena uz korišćenje drugih lekova kao dodataka lokalnim anesteticima. Deksametazon, primenjen kao do- datni lek, za blokiranje perifernih nerava, pokazao se kao odličan lek, koji produžava vreme postoperativne analgezije. Studija je randomizovana, prospektivna i dvostruko slepa i kontrolisana studija.

Cilj: Studija je dizajnirana da uporedi efekte deksametazona, koji je primenjen kao dodatak bupivakainu u interskalenskom bloku pleksusa brahijalisa na početku, tokom trajanja i postoperativne analgezije kod pacijenata, podvrgnutih operaciji ramena.

Metoda: Prospektivnoj, dvostruko slepoj studiji su podvrgnuti pacijenti, kojima je zakazana operacija 
ramena pod interskalenim blokom pleksusa brahijalisa. Uključili smo 60 pacijenta, ASA I-II oba pola, uzrasta 19-65 godina, težine $54-89 \mathrm{~kg}$, podeljenih u dve grupe G1 i G2. Blok brahijalnog pleksusa je izveden interskalenim pristupom i miksturom $2 \%$ lidokaina (12 $\mathrm{ml})$ i 0,5\% bupivakaina $(22 \mathrm{ml}$ ) bilo samih ili u kombinaciji sa deksametazonom (4 mg). Blok je postignut korišćenjem duple tehnike, neurostimulator/ultrazvuk tehnike.

Rezultati: U našem istraživanju smo našli značajan porast na početku i tokom trajanja, motornog i sen-

\section{REFERENCES}

1. Golwala MP, Swadia VN, Dhimar AA, Sridhar NV. Pain relief by dexamethasone as an adjunct to local anaesthetics in supraclavicular brachial plexus block. J Anaesthesiol Clin Pharmacol. 2009; 25(3): 285-8.

2. Mc Cartney C, Duggan E Apatu E. Should we add clonidine to local anesthetic for peripherial nerve blockade? A qualitative systematic review of the literature. Reg Anesth Pain Med. 2007; 32(4): 330-8.

3. Choi R, Rodseth C, Mc Cartney J. Effects of dexamethason as local anesthetic adjuvant for brachial plexus block: a systematic review and meta-analysis of randomized trials. Br. J Anaesth. 2014; 112(3): 427-39.

4. Vieira PA, Pulai I, Tsao GC, Manikantan P, Keller B, Connelly NR. Dexamethason with bupivacain increases duration of analgesia in ultrasound- guided interscalene brachial plexus blockade. Eur J Anaesthesiolog. 2010; 27(3): 285-8.

5. Desmet M, Braems H, Reynovet M et al. I.V. and perineural dexamethasone are equivalent in increasing the analgesic duration of a single- shot interscalene block with ropivacaine for shoulder surgery: a prospective, randomized, placebo-controlled study.Br. J Anaesth. 2013; 111(3): 445-52.

6. Axelsson K, Gupta A. Local anaesthetic adjuvans:neuroaxial versus peripherial nerve block.Curr Opinion in Anaesthesiol. 2009; 22(5): 649-54.

7. Murphy DB, McCartney CJ, Chan VW. Novel analgesic adjuncts for brachial plexus block: a systematic review. Anesth Analg. 2000; 90(5): 1122-8.

8. Strichartz GR, Berde CB. Local anesthetics. In: Miller RD, editor. Miller's anesthesia. 6th ed. Philadelphia: Elsevier Churchill Livingstone; 2005. pp. 573-603.

9. Biradar PA, Kaimar P, Gopalakrishna K. Effect of dexamethasone added to lidocaine in supraclavicular brachial plexus block: A prospective, randomised, double-blind study. Indian Journal of Anaesthesia. 2013; 57(2): 180-4.

10. Kumar S, Palaria U, Sinha AK, Punera DC, Pandey V. Comparative evaluation of ropivacaine and ropivacaine with de- zornog bloka u Grupi 2 (sa deksametazonom) u poređenju sa Grupom $1(\mathrm{p}<0,01)$.

Zaključak: Dodavanje deksametazona lokalnim anesteticima u interskalenom bloku pleksusa brahialisa, značajno produžava vreme trajanja analgezije i bloka motornih funkcija kod pacijenata podvrgnutih artroskopiji ramena. Šta više, pokazao se kao izuzetno siguran i ekonomičan metod u obezbeđivanju postoperativne analgezije.

Ključne reči: regionalna anestezija, interskalenskii blok pleksusa, adjuvansi, deksametazon.

xamethasone in supraclavicular brachial plexus block for postoperative analgesia. Anesth Essays Res. 2014; 8(2): 202-8.

11. Shaikh MR, Majumdar S, Das A. Role of Dexamethasone In Supraclavicular Brachial Plexus Block.IOSR-JDMS. 2013; 12: 1-7.

12. Persec J, Persec Z, Kopljar M, et al. Low-dose dexamethasone with levobupivacaine improves analgesia after supraclavicular brachial plexus blockade. Int Orthop. 2014; 38(1): 101-5.

13. Pathak RG, Satkar AP, Khade RN. Supraclavicular brachial plexus block with and without dexamethasone - A comparative study. Int J Sci Res Publi. 2012; 2: 1-7.

14. Parrington SJ, O’Donnell D, Chan VW, at al. Dexamethasone added to mepivacaine prolongs the duration of analgesia after supraclavicular brachial plexus blockade.Reg Anesth Pain Med. 2010; 35(5): 422-6.

15. Shrestha BR, Maharjan SK, Shrestha S, et al. Comparative study between tramadol and dexamethasone as an admixture to bupivacaine in supraclavicular brachial plexus block. JNMA J Nepal Med Assoc. 2007; 46(168): 158-64.

16. Movafegh A, Razazian M, Hajimaohamadi F, Meysamie A. Dexamethasone Added to Lidocaine Prolongs Axillary Brachial Plexus Blockade. Anesth Analg. 2006; 102(1): 263-7.

17. Cummings KC, Napierkowski DE, Para-Sanchez I, et al. Effect of dexamethasone on the duration of interscalene nerve blocks with ropivacain or bupivacaine. Br J Anaesth 2011; 107: 446-53.

18. Shahedha P, Vardhan V, Lakhami B. Efect of intravenous dexamethasone in prolonging the duration of supraclavicular brachialis plexus block with 0.55 ropivacaine; a prospective randomized, placebo controlled study. Int J of Scientic Study. 2015; 2(10): 56-60.

19. Mahmoud M, Azza A, Heffni A. Dexamethasone bupivacaine versus bupivacaine for peribulbar block in posterior segment eye susrgery. Egiptian J of Anaesthesia. 2013; 29(4): 407-11.

20. Stan T, Goodman EJ, Bravo-Fernandez C, Holbrook CR. Adding methylprednisolone to local anesthetic increases duration of axillary block. Reg Anesth Pain Med. 2004; 29(4): 380-1.

\section{Correspondence to/ Autor za korespondenciju}

Associate Prof. Dr. Jasminka Nancheva

Clinic for Orthopaedic Surgery, Medical Faculty, University "St. Kiril and Metodij"

17 Mother Tereza, 1000, Skopje, Rep. of Macedonia

$\mathrm{mob} /++38970365291$

e-mail: jasminkananceva@yahoo.com 